\title{
DESAIN PEMBELAJARAN GARIS DAN SUDUT MENGGUNAKAN JAM DINDING LINGKARAN UNTUK SISWA SMP KELAS VII
}

\author{
Ajeng Ramadhani ${ }^{1}$, Rully Charitas Indra Prahmana ${ }^{2}$ \\ ${ }^{1,2}$ Universitas Abmad Dablan Yogyakarta \\ Corresponding Author: rully.indra@mpmat.uad.ac.id
}

\begin{abstract}
The purpose of this research is to understanding the role of line and angle learning design in students' comprehension of mathematical concept and also to understanding the students' learning result through LAS (Lembar Aktivitas Mabasiswa) or student activity paper that is based on the Indonesian Realistic Mathematics Education approach. The research method used in this research is design research. The result of this research shows that the activity of using props or drawing a clock circle could motivate the students in checking out the shaped angle, So the students will have the idea to calculate how big is the angle that is shaped by the clockwise and also to determine its types. So, the design that is used could help the students to understanding the concept of angle through the context of clock circle.
\end{abstract}

Keyword: Indonesian Realistic Mathematics Education, Line and Angle, Design Research.

How to cite: Ramadhani, A., \& Prahmana, R.C.I. (2019). Desain Pembelajaran Garis dan Sudut menggunakan Jam Dinding Lingkaran untuk Siswa SMP Kelas VII. JRPM (Jurnal Review Pembelajaran Matematika), 4(2), 85-101.

\section{PENDAHULUAN}

Pelajaran matematika merupakan salah satu pelajaran yang dianggap sulit dari jenjang Pendidikan Dasar hingga jenjang Pendidikan Menengah oleh masyarakat umum (Herawati, Siroj, \& Basir, 2010). Selanjutnya, Afrilianto (2012) menyatakan bahwa matematika merupakan salah satu ilmu yang memiliki peranan penting dalam perkembangan Sains dan Teknologi. Selain itu, matematika juga memiliki manfaat bagi bidang yang lain, seperti yang dikatakan Khoirudin dan Rizkianto (2018) yang menjelaskan bahwa matematika sangat diperlukan baik dalam kehidupan sehari-hari maupun dalam menghadapi kemajuan IPTEK sehingga matematika perlu dibekalkan kepada siswa dari jenjang Pendidikan Dasar hingga jenjang Pendidikan Menengah. Oleh karena itu, dapat dikatakan bahwa matematika merupakan mata pelajaran yang penting karena memiliki manfaat pada bidang Sains dan Teknologi serta sangat diperlukan dalam kehidupan sehari hari yang perlu dibekalkan sejak dini.

Pemahaman konsep sangat penting bagi siswa dalam mempelajari matematika karena konsep matematika yang satu dengan yang lain saling berkaitan sehingga untuk mempelajarinya harus runtut dan berkesinambungan (Akmil, Armiati, \& Rizal, 2012). 
Selanjutnya, pemahaman konsep perlu ditanamkan pada anak sejak dini yaitu sejak siswa tersebut berada di bangku Sekolah Dasar hingga ke jenjang pendidikan yang lebih tinggi (Herawati, dkk. 2010). Hal yang diperlukan dalam belajar matematika adalah kemampuan untuk memahami konsep-konsep dengan melibatkan tindakan untuk mengetahui konsep dan prinsip-prinsip yang berkaitan dengan prosedur dan berhubungan atau menciptakan hubungan yang bermakna antar konsep yang ada dengan konsep yang baru dipelajari (Purwanti, Pratiwi, \& Rinaldi, 2016). Selanjutnya, Susanto (2015) menyatakan bahwa siswa dikatakan memiliki kemampuan pemahaman konsep jika memiliki kemampuan merumuskan strategi penyelesaian, menerapkan perhitungan sederhana, menggunakan simbol untuk mempresentasikan konsep, dan dapat mengubah suatu bentuk ke bentuk lain yang berkaitan dengan pecahan. Oleh karena itu para guru diharapkan mampu memberikan pemahaman konsep matematika sejak dini kepada peserta didik, yaitu sejak peserta didik tersebut berada di bangku Sekolah Dasar hingga ke jenjang pendidikan yang lebih tinggi.

Sejumlah peneliti telah mendokumentasikan hasil penelitiannya terkait Pendidikan Matematika Realistik Indonesia (PMRI) (Zulkardi \& Putri, 2010; Simanulang, 2013; Fitri \& Prahmana, 2018). PMRI adalah teori pembelajaran yang bertitik tolak dari hal-hal yang 'real atau nyata dan pernah di alami siswa, menekankan keterampilan proses 'doing mathematics' dengan berduskusi dan berkolaborasi, serta berargumentasi dengan teman sekelas, sehingga siswa dapat menemukan sendiri atau 'student inventing' sebagai kebalikan dari 'teacher telling', dan menggunakan matematika untuk menyelesaikan masalah baik secara individu maupun kelompok (Zulkardi \& Putri, 2010). Berdasarkan hasil penelitian Simanulang (2013) menyatakan bahwa dengan menggunakan pendekatan PMRI pada suatu pembelajaran, mampu membuat siswa berpikir kritis dan kreatif, sehingga mampu memahami konsep matematika. Hal tersebut didukung oleh penelitian Fitri dan Prahmana (2018) yang menyatakan bahwa pendekatan PMRI dianggap mampu membantu siswa untuk meningkatkan pemahaman konsep matematika menggunakan berbagai hal yang dekat dengan siswa dan sering ditemui dalam kehidupan sehari-hari. Sehingga salah satu pendekatan pembelajaran yang dapat mengembangkan pemahaman konsep matematika siswa adalah menggunakan pendekatan Realistic Mathematics Education (RME) atau di Indonesia disebut Pendidikan Matematika Realistik (PMR) dan Pendidikan Matematika Realistik Indonesia (PMRI).

Berdasarkan hasil-hasil penelitian terdahulu menunjukkan bahwa kemampuan pemahaman konsep matematika siswa masih rendah atau belum sesuai dengan yang 
diharapkan. Seperti pada hasil penelitian Afrilianto (2012) diperoleh bahwa pemahaman konsep dan kompetensi strategis matematis dinilai masih belum optimal dimiliki siswa. Menurut Purwanti, dkk. (2016), siswa banyak mengalami kesulitan dalam menyelesaikan soal-soal yang menuntut pemahaman konsep matematis yang menentukan keberhasilan belajar matematika siswa. Selanjutnya, Sari (2014) dalam penelitiannya menyatakan bahwa siswa terbiasa menerima berbagai macam rumus sehingga tidak memiliki kesiapan individu dalam memahami konsep secara mendalam.

Susilowati (2017) menyatakan bahwa materi garis dan sudut, banyak diaplikasikan dalam kehidupan sehari-hari misalnya, pada bidang pertukangan, transportasi dan lain-lain sehingga materi tersebut penting untuk dipelajari. Hal tersebut di dukung oleh hasil penelitian Wachidah (2015) yang menyatakan bahwa materi garis dan sudut merupakan konsep dasar untuk mempelajari materi selanjutnya seperti dalam membuktikan rumusrumus pada materi bangun datar segitiga dan segi empat, yang banyak diterapkan dalam kehidupan sehari-hari misalnya, sudut antara jarum pendek dengan jarum panjang, sudut pada atap rumah, meja, kursi, dan yang lainnya. Selanjutnya, berdasarkan hasil penelitian Suryanti (2015) diperoleh bahwa dalam menyelesaikan setiap permasalahan pada pokok bahasan garis dan sudut diperlukan pemahaman konsep dan prinsip yang matang karena soal-soal garis dan sudut dikreasikan dengan menyajikan bentuk-bentuk atau gambar, sehingga materi garis dan sudut penting untuk dipelajari karena banyak diaplikasikan dalam kehidupan sehari-hari.

Berdasarkan uraian di atas, dapat ditunjukkan bahwa pendekatan PMRI dapat digunakan sebagai salah satu treatment yang dapat memberikan pemahaman atas konsep garis dan sudut yang merupakan materi yang penting untuk dipelajari dan banyak aplikasinya dalam kehidupan sehari-hari. Oleh karena itu, peneliti mendesain pembelajaran materi garis dan sudut menggunakan pendekatan PMRI, yang diharapkan dapat dimanfaatkan oleh peneliti berikutnya dalam pembelajaran materi garis dan sudut menggunakan pendekatan PMRI.

\section{METODE PENELITIAN}

Penelitian ini merupakan penelitian kualitatif deskriptif yang mendeskripsikan peran konteks jam dinding lingkaran pada pembelajaran garis dan sudut. Prosedur penelitian ini meliputi tahap persiapan, tahap pelaksanaan, dan analisis data (Prahmana, 2017). Penelitian ini dilakukan pada semester genap tahun akademik 2018/2019 di SMP Muhammadiyah Al 
Mujahidin Wonosari. Subjek penelitian ini adalah seluruh siswa kelas VII E SMP Muhammadiyah Al Mujahidin Wonosari yang dipilih secara purposive sampling. Objek pada penelitian ini adalah pengenalan konsep matematika pada materi garis dan sudut.

Teknik pengumpulan data yang digunakan dalam penelitian ini adalah rekaman video, dokumentasi, data tertulis, observasi, dan wawancara (Prahmana, 2017). Selanjutnya, instrumen pengumpulan data yang digunakan yaitu video, foto, lembar tes tertulis siswa, dan lembar catatan lapangan, serta lembar wawancara. Seluruh data yang diperoleh pada penelitian di analisis menggunakan triangulasi data untuk mendeskripsikan peran dari aktivitas yang telah di desain selama proses pembelajaran. Selanjutnya, pada akhir pembelajaran dilakukan evaluasi akhir untuk melihat perubahan nilai atas peran konteks yang diberikan selama proses pembelajaran terhadap hasil belajar siswa.

\section{HASIL DAN PEMBAHASAN}

Penelitian ini dilaksanakan sebanyak 2 kali pertemuan. Pada pertemuan pertama, siswa mengerjakan Lembar Aktivitas Siswa (LAS) 1 secara berkelompok yang setiap kelompoknya beranggotakan 4 sampai dengan 5 siswa. Pada pertemuan kedua, siswa mengerjakan LAS 2 secara berkelompok yang setiap kelompoknya beranggotakan 4 sampai dengan 5 siswa. Selanjutnya, pada pertemuan ketiga dilaksanakan tes evaluasi. Untuk lebih jelasnya dapat dilihat pada Tabel 1.

Tabel 1. Jadwal Pelaksanaan Kegiatan Pembelajaran

\begin{tabular}{clcl}
\hline Pertemuan & \multicolumn{1}{c}{ Kegiatan Siswa } & Hari, Tanggal & \multicolumn{2}{c}{ Materi } \\
\hline I & LAS 1 & Jum'at, 05 April 2019 & $\begin{array}{l}\text { Besar sudut dan jenis-jenis } \\
\text { sudut }\end{array}$ \\
II & $\begin{array}{l}\text { LAS 2 dan Tes } \\
\text { Evaluasi }\end{array}$ & Selasa, 09 April 2019 & Konsep sudut \\
\hline
\end{tabular}

Pembelajaran besar sudut, jenis-jenis sudut, dan konsep sudut dilakukan di kelas VII E dengan menggunakan instrumen tes tertulis yang telah divalidasi sebelumnya. Pada kegiatan pembelajaran materi besar sudut, jenis-jenis sudut, dan konsep sudut dilaksanakan dengan menggunakan bantuan alat peraga yaitu jam dinding berbentuk lingkaran. Dari pembelajaran, didapatkan hasil observasi pembelajaran sudut berupa catatan lapangan dan analisis data tes tertulis. Berikut ini adalah penjabaran kegiatan guru, kegiatan siswa dan hasil data tes tertulis dalam pembelajaran perbandingan senilai yang telah dilakukan oleh peneliti: 


\section{Deskripsi dan Analisis Kegiatan Pembelajaran Garis dan Sudut}

\section{a. Pertemuan I}

Pada awal pembelajaran, guru menyapa siswa dengan mengucapkan salam, menyuruh siswa mempersiapkan buku pelajaran dan alat tulis, kemudian mengecek kehadiran siswa. Guru memulai pembelajaran dengan memberikan pengetahuan bahwa konsep sudut sering dibutuhkan oleh seseorang dalam kehidupan sehari-hari. Selanjutnya guru mengajarkan siswa cara menghitung sudut menggunakan jarum jam panjang dan jarum jam pendek dengan bantuan jam dinding lingkaran. Kemudian, guru memulai kegiatan pembelajaran dengan memberikan arahan kepada siswa untuk berdiskusi menggunakan LAS. Pada saat siswa mengerjakan LAS, guru berkeliling kelas untuk mengecek pekerjaan kelompok dan memberikan bantuan kepada kelompok yang mengalami kesulitan. Salah satu kasus kesulitan yang didapatkan yaitu siswa kesulitan dalam menentukan besar sudut pada jam dinding lingkaran, sehingga terdapat siswa yang bertanya tentang bagaimana cara menetukan besar sudut menggunakan jam dinding yang berbentuk lingkaran. Kasus ini sesuai dengan dugaan yang dibuat oleh peneliti. Untuk lebih jelasnya dapat dilihat pada Dialog 1 dan Gambar 1.

Dialog 1:

Zafran : Ini kan jam lima ya, Us. Nah sudut terkecilnya berarti dua pulub lima menit kan. Berarti dua pulub lima kali enam?

Guru : Bukan. Ini lompatannya kan satu, dua, tiga, empat, lima. Berarti lima kali berapa?

Fathin : :Tiga puluh.

Guru : Berapa?

Zafran : Seratus lima puluh.

Guru : Sama ngga kayak yang tadi?

Zafran : (Mengangguk-anggukekan kepala)

Guru : : Di tulis dua aja juga boleh gitu.

Zaldy : Satu boleh?

Guru : : Duajuga boleh.

Stevano : Satu ngga papa, Us.

Guru : Dua saja. Ayo buruan di tulis. 


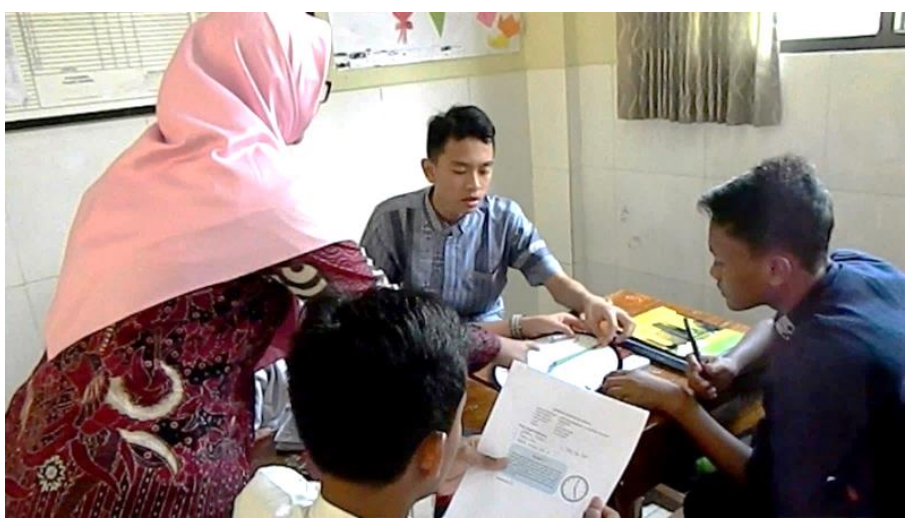

Gambar 1. Siswa Bertanya Tentang Bagaimana Cara Menetukan Besar Sudut Menggunakan Jam Dinding yang Berbentuk Lingkaran

Beberapa kelompok lain juga mengalami permasalahan yang sama yaitu siswa kesulitan dalam menentukan besar sudut pada jam dinding lingkaran. Sehingga beberapa kelompok bertanya kepada guru. Selain itu, terdapat kelompok yang kesulitan dalam menuliskan besar sudut pada permasalahan 1.3 tentang jenis-jenis sudut berdasarkan besar sudutnya. Sehingga guru membantu kelompok tersebut dalam menentukan jenisjenis sudut berdasarkan besar sudut yang dibentuk antara jarum jam panjang dan jarum jam pendek. Kasus ini juga sesuai dengan dugaan yang dibuat oleh peneliti. Untuk lebih jelasnya dapat dilihat pada Dialog 2 dan Gambar 2.

Dialog 2:

Guru : Tadi katanya sudut reflek yang ini (Sambil menunjuk sudut reflek pada alat peraga jam dinding lingkaran). Berapa besarnya? Dari berapa sampai berapa? Seratus delapan puluh sampai? Tiga ratus enam puluh. Gitu ya?

Zaldy $\quad$ : Iya (Sambil menganggukekan kepala).

Guru : Kalau sudut lancip berapa?

Zafran : Sembilan pulub sampai nol.

Guru : : Dari nol sampai sembilan puluh. Kalau sudut tumpul?

Zafran : Sembilan pulub sampai seratus delapan pulub.

Zaki : Sembilan puluh sampai seratus delapan pulub.

Guru : : Kalau lurus?

Zafran : : Seratus delapan puluh.

Guru :Hah?

Zafran : Seratus delapan pulub.

Stevano : Seratus delapan puluh. 


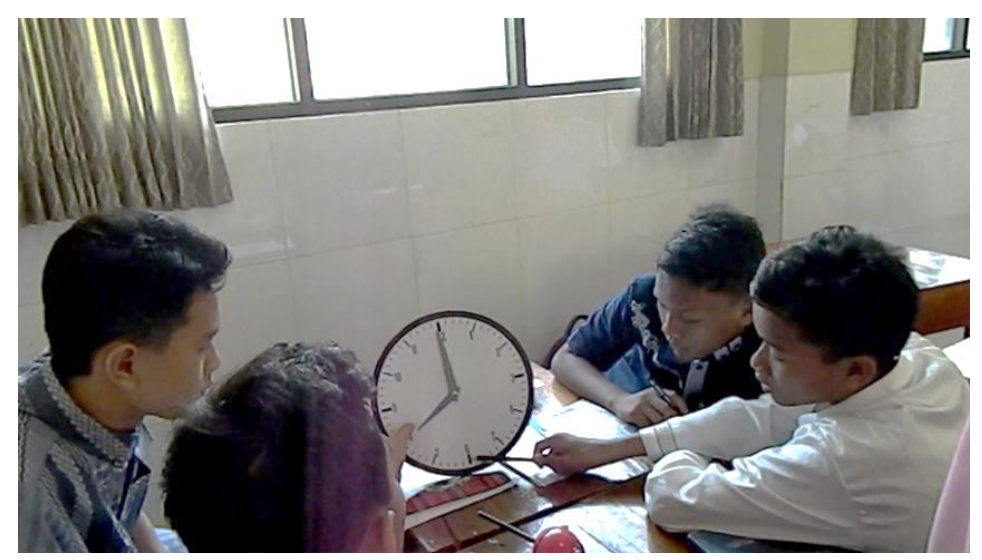

Gambar 2. Guru Membantu Siswa dalam Menentukan Jenis-Jenis Sudut Berdasarkan Besar Sudut

Terdapat kelompok yang kesulitan dalam menentukan pukul berapa saja ketika besar sudut terkecil yang dibentuk oleh kedua jarum jam membentuk sudut sebesar $90^{\circ}$ dalam satu hari satu malam. Dengan sigap, guru membimbing siswa dalam menjawab permasalahan tersebut menggunakan alat peraga jam dinding lingkaran. Terlihat siswa memutar kedua jarum jam dinding lingkaran hingga membentuk suatu sudut. Hal tersebut sesuai dengan dugaan yang dibuat oleh peneliti. Untuk lebih jelasnya dapat dilihat pada Dialog 3 dan Gambar 3.

Dialog 3:

Fathin :Ini boleh, Us? (Sambil menggeser-geser kedua jarum jam pada alat peraga jam dinding lingkaran hingga membentuk sudut sembilan pulub derajat)

Guru : Boleh. Kalau gini boleh ngga? Ada ngga ini? (Sambil menggeser kedua jarum jam Hamrah : :Ada.

Guru $\quad$ : Ya engga, orang setengah tiga itu jarum pendeknya ngga pas di angka tiga.

Fathin : Kamu itu gimana sib, $\mathrm{Za}$ ? Ab!

Guru :Iyakan?

Fathin :Iya.

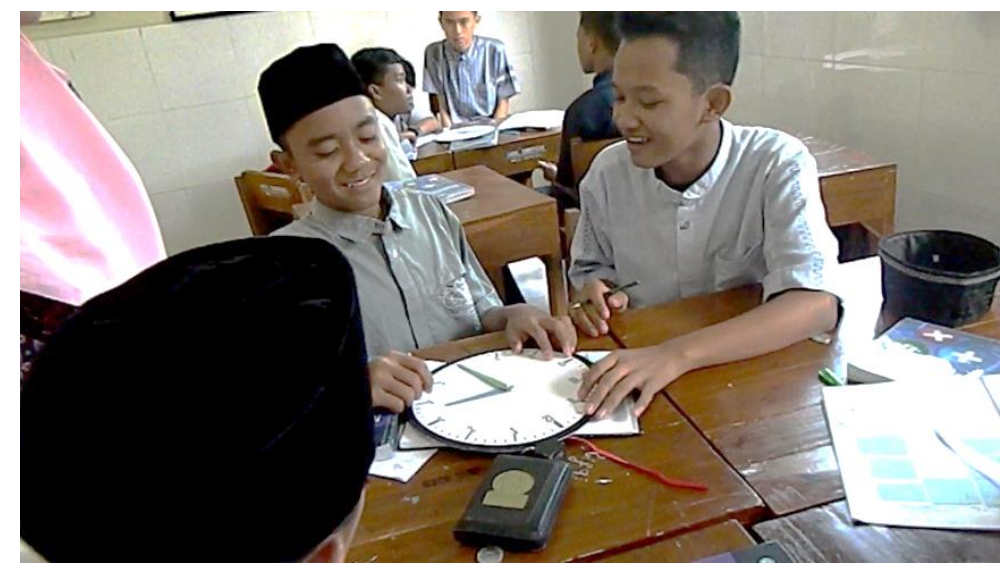

Gambar 3. Guru Membimbing Siswa dalam Menjawab Permasalahan dalam LAS 
Kegiatan selanjutnya adalah mempresentasikan hasil diskusi LAS, yang diwakilkan oleh dua kelompok. Pada saat guru berkeliling di kelas untuk mengecek pekerjaan kelompok, guru juga menawarkan beberapa kelompok untuk maju kedepan dan mempresentasikan hasil diskusinya. Kemudian guru mereview kembali materi pembelajaran yang telah dipelajari dengan cara menjelaskan konsep sudut menggunakan jam dinding lingkaran dan memberikan pertanyaan kepada seluruh siswa. Setelah selesai mereview materi pembelajaran yang telah dipelajari, guru menginformasikan materi yang dipelajari untuk pertemuan selanjutnya dan menyarankan siswa untuk mempelajarinya terlebih dahulu di rumah. Selanjutnya guru menutup pembalajaran tersebut dengan mengucapkan salam.

\section{b. Pertemuan II}

Pada awal pembelajaran, guru menyapa siswa dengan mengucapkan salam, menyuruh siswa mempersiapkan buku pelajaran dan alat tulis, kemudian mengecek kehadiran siswa. Guru memulai pembelajaran dengan memberikan gambaran materi yang dipelajari pada pertemuan tersebut dan mereview kembali materi pertemuan yang lalu yaitu tentang besar sudut dan jenis-jenis sudut berdasarkan besar sudutnya. Selanjutnya, guru mengajarkan cara menghitung besar sudut pada jam dinding lingkaran melalui jarum jam panjang dan jarum jam pendek pada jam dinding lingkaran.

Selanjutnya guru menginformasikan bahwa di akhir pelajaran diadakan tes evaluasi mengenai materi sudut yang telah dipelajari. Setelah itu, guru membagi kelompok yang setiap kelompoknya terdiri dari 4 sampai dengan 5 siswa, dan dibagikan sebuah jam dinding lingkaran, serta LAS di setiap kelompok. Guru memberikan arahan kepada siswa untuk berdiskusi dalam menyelesaikan permasalahan sudut pada LAS.

Pada saat siswa mengerjakan LAS, guru berkeliling kelas untuk mengecek pekerjaan kelompok dan memberikan bantuan kepada kelompok yang mengalami kesulitan. Salah satu kasus kesulitan yang didapatkan yaitu siswa tidak dapat memahami konsep sudut yang diterapkan dalam kehidupan sehari-hari, sehingga terdapat siswa yang bertanya kepada guru. Kasus ini sesuai dengan dugaan yang dibuat oleh peneliti. Untuk lebih jelasnya dapat dilihat pada Dialog 4 dan Gambar 4.

Dialog 4:

Guru : Jam tiga lima pulub lima begini kan?

Abdul :Iya.

Guru : Kenapa bisa ditambabin ya?

Alvito :Karena sudut terkecil.

Guru : Jadi kalau kamu ngitung ini, ditambah yang ini, jadi sudut terbesar. Dan ini kan 
jaraknya kecil. Ini kan sudah jelas (Sambil menunjuk kedua sudut yang dibentuk kedua jarum jam pada alat peraga jam dinding lingkaran).

Alvito : Iya.

Guru : Kalau yang ini dikurang, yang ini ditambah. Gitu ya?

Siswa : (Beberapa siswa menganggukkean kepala)

Guru : Sip (Sambil memberikan acungan jempol).

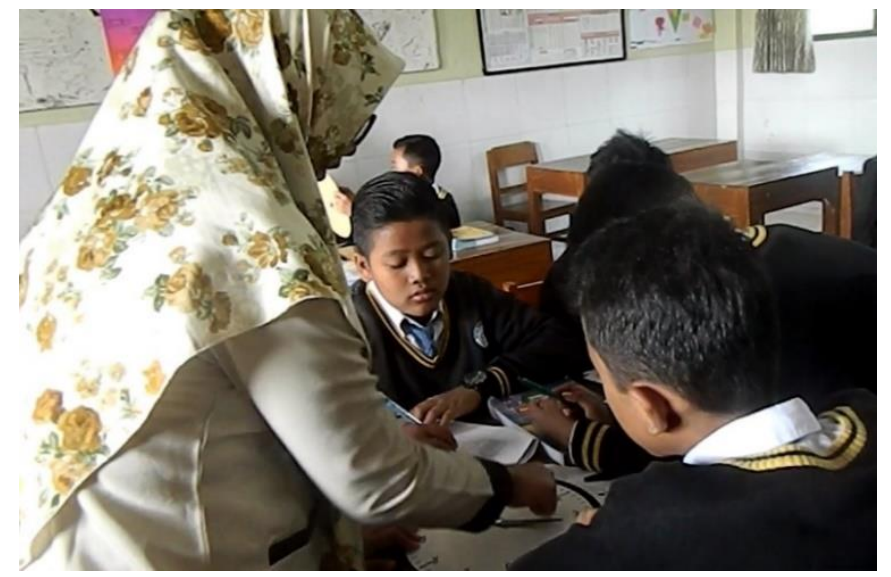

Gambar 4. Siswa Bertanya Kepada Guru Tentang Cara Penyelesaiannya Permasalahan dalam LAS

Terdapat juga beberapa kelompok yang dapat memahami konsep sudut yang diterapkan dalam kehidupan sehari-hari dan dapat terampil dalam menyelesaikan permasalahan terkait sudut pada jam dinding lingkaran dalam LAS. Hal tersebut sesuai dengan dugaan yang dibuat oleh peneliti.

Siswa melanjutkan berdiskusi dengan teman satu kelompoknya untuk menyelesaikan permasalahan-permasalahan di dalam LAS setelah mendapatkan bimbingan pemahaman konsep sudut dari guru. Selanjutnya, guru melanjutkan mengelilingi kelas untuk mengecek pekerjaan siswa dan membantu siswa yang kesulitan dalam menyelesaikan permasalahan-permasalahan yang ada di dalam LAS.

Kegiatan selanjutnya adalah mempresentasikan hasil diskusi LAS, yang diwakilkan oleh dua kelompok. Pada saat guru berkeliling di kelas untuk mengecek pekerjaan kelompok, guru juga menawarkan beberapa kelompok untuk maju kedepan dan mempresentasikan hasil diskusinya.

Kegiatan selanjutnya yaitu guru mengumpulkan LAS seluruh kelompok dan mengambil kembali alat peraga jam dinding lingkaran serta menyuruh seluruh siswa untuk memasukkan buku. Kemudian guru mereview kembali materi pembelajaran yang telah dipelajari dengan cara menjelaskan konsep sudut yaitu cara menghitung besar sudut yang dibentuk kedua jarum jam dinding lingkaran. Setelah itu, guru menyuruh siswa untuk menyiapkan alat tulis dan menginformasikan bahwa diadakan tes evaluasi. 
Selanjutnya guru membagikan soal tes evaluasi kepada seluruh siswa. Setelah waktu untuk mengerjakan tes evaluasi yang telah ditentukan habis, guru segera mengambil seluruh pekerjaan siswa. Setelah semua siswa mengumpulkan lembar tes evaluasi, guru menutup pembelajaran dengan mengucapkan salam.

\section{Deskripsi dan Analisis Data Tes Tertulis}

Data tes tertulis digunakan untuk mengetahui kemampuan siswa pada materi konsep sudut. Tes tertulis dilaksanakan pada pertemuan kedua (posttest). Tes tertulis ini dilaksanakan untuk mengetahui kemampuan siswa setelah diberikan treatment. Hasil tes tertulis (posttest) nomor 1 menunjukkan bahwa hanya terdapat 2 orang siswa yang jawabannya belum benar yaitu Fata (Ft) dan Alvito (Al). Untuk lebih jelasnya, dapat dilihat pada Gambar 5.

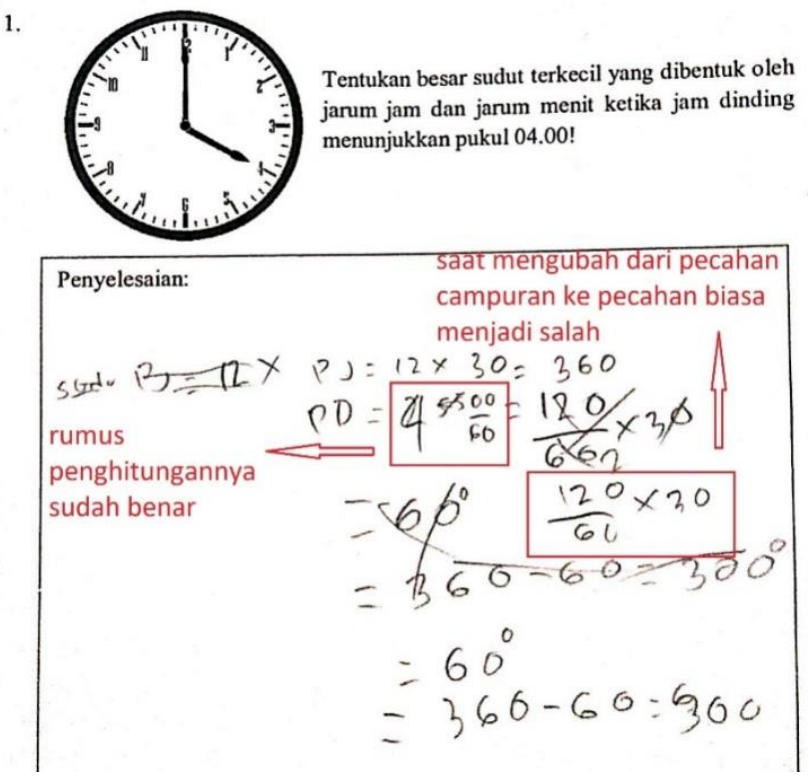

Gambar 5. Jawaban Tes Tertulis Fata Nomor 1

Pada Gambar 5 menunjukkan bahwa Ft belum dapat menghitung dengan benar besar sudut menggunakan jarum panjang pada jam dinding lingkaran. Sedangkan untuk penghitungan sudut yang dibentuk oleh kedua jarum jam pada jam dinding lingkaran, Ft sebenarnya sudah menggunakan rumus yang benar, tetapi proses penghitungan pada saat mengubah pecahan campuran menjadi pecahan biasanya salah, sehingga hasil akhirnya juga salah. Berbeda lagi dengan jawaban tes tertulis yang dituliskan oleh Al. Untuk lebih jelasnya, dapat dilihat pada Gambar 6. 


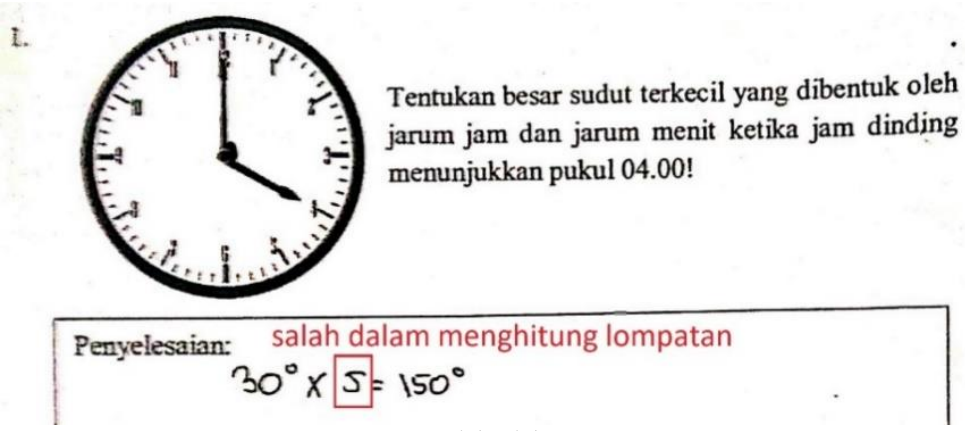

Gambar 6. Jawaban Tes Tertulis Al Nomor 1

Gambar 6 memperlihatkan bahwa Al sebenarnya sudah menggunakan rumus yang benar. Kesalahannya terdapat dalam menghitung lompatan jarum pendek pada jam dinding lingkaran. Pada jawaban Al tertulis bahwa lompatan jarum pendek tersebut adalah 5, sedangkan yang benar adalah 4. Seharusnya $\mathrm{Al}$ menghitung dari angka 1 hingga 4 bukan dari angka 12 hingga 4 . Kesalahan ini mengakibatkan hasil akhir yang diperoleh salah.

Selanjutnya hasil evaluasi nomor 2, terdapat 4 siswa yang nilainya belum sempurna, sedangkan 17 siswa lainnya sudah benar. Keempat siswa tersebut adalah Fata (Ft), Icas (Ic), Stefano (St), dan Arya (Ar). Keempat siswa tersebut memiliki tipe kesalahan yang sama yaitu jawaban yang dituliskan masih belum lengkap dan kurang menuliskan besar sudutnya.

Selanjutnya, terdapat 20 siswa yang dapat menjawab soal nomor 3 dengan benar dan terdapat 1 siswa yang jawabannya masih belum benar. Siswa tersebut bernama Ic. Ic masih belum dapat memahami soal nomor tiga. Hal tersebut dapat dilihat dari penghitungan jarum jam pendek, jarum jam panjang, dan besar sudut terkecil Ic yang masih salah.

Hasil evaluasi untuk soal nomor 4, menunjukkan bahwa terdapat 3 jawaban siswa yang masih belum seluruhnya benar. Ketiga siswa tersebut adalah Alvito (Al), Raihan (Ra), dan Fata (Ft). Kesalahan-kesalahan yang dilakukan ketiga siswa tersebut menunjukkan bahwa ketiga siswa tersebut masih belum paham tentang menentukan jam jika diketahui besar sudutnya.

Hasil evaluasi untuk soal nomor 5, menunjukkan bahwa soal tersebut merupakan soal yang paling banyak mengecoh siswa. Hal tersebut dikarenakan dari 21 siswa, terdapat 8 orang siswa yang jawabannya belum seutuhnya benar. Kesalahan-kesalahan yang dialami siswa dikelompokkan menjadi 3 tipe kesalahan. Kesalahan yang pertama merupakan kesalahan dalam menghitung besar sudut jarum panjang. Kesalahan tipe ini 
dialami oleh Zaki $(\mathrm{Za})$ dan Naufal $(\mathrm{Na})$. Tipe kesalahan nomor 5 yang kedua adalah kesalahan dalam menghitung besar sudut jarum jam pendek dan kesalahan dalam menggambar sudut terkecil. Kesalahan tipe ini dialami oleh Raihan (Ra) dan Stefano (St). Tipe kesalahan nomor 5 yang ketiga dialami oleh Alvito (Al), Icas (Ic), Zaldy (Za), dan Arya (Ar). Kesalahan pada tipe ini adalah siswa belum dapat menentukan besar sudut terkecil.

Berdasarkan hasil evaluasi tes tertulis, terdapat 4 siswa yang nilainya berada dibawah Kriteria Ketuntasan Minimum (KKM). Sedangkan nilai 17 siswa yang lainnya, berada di atas KKM dan dari 17 siswa yang berada di atas KKM tersebut, terdapat 7 siswa yang mendapat nilai 100. KKM SMP Muhammadiyah Al Mujahidin Wonosari Gunungkidul adalah 75. Tabel 2 yang menunjukkan nilai tes evaluasi siswa kelas VII E SMP Muhammadiyah Al Mujahidin Wonosari Gunungkidul.

Tabel 2. Kategori Nilai Tes Evaluasi

\begin{tabular}{cccc}
\hline Kategori & Nilai & Frekuensi & Persentase \\
\hline Tuntas & $\geq 75$ & 17 & $80,952 \%$ \\
Tidak Tuntas & $<75$ & 4 & $19,048 \%$
\end{tabular}

Tabel 2 menunjukkan bahwa siswa yang tuntas sebanyak 80,952\%, sedangkan siswa yang tidak tuntas adalah sisanya yaitu 19,048\%. Kegiatan tes evaluasi tersebut diikuti oleh 21 siswa. Rata-rata nilai tes evaluasi siswa adalah adalah 84,048.

Peran desain pembelajaran garis dan sudut dengan menggunakan konteks jam dinding lingkaran dalam pemahaman konsep tersebut adalah bahwa aktivitas menggunakan alat peraga atau menggambar jam dinding lingkaran dapat mendorong siswa untuk melihat bentuk sudut yang terbentuk, dan ketika siswa melihat bentuk sudut tersebut, siswa memiliki ide untuk menghitung besar sudut yang di bentuk oleh kedua jarum jam dan dapat menentukan jenis-jenis sudut tersebut berdasarkan besar sudutnya. Sehingga, hasil penelitian ini menambah bukti empiris peran konteks yang relevan terhadap pemahaman suatu topik tertentu dalam pembelajaran matematika, sebagaimana telah diteliti oleh sejumlah penelitian sebelumnya (Edo \& Bulu, 2018; Mumu \& Tanujaya, 2018; Risdiyanti, Prahmana, \& Shahrill, 2019; Sary \& Ristiana, 2019; Hanum \& Prahmana, 2019). Hal tersebut didukung dengan hasil wawancara peneliti dengan guru yang menyatakan bahwa desain pembelajaran garis dan sudut menggunakan jam dinding lingkaran tersebut dapat membantu siswa dalam memahami materi pelajaran 
garis dan sudut, sehingga hasil belajar siswa baik. Selain itu, pada saat kegiatan pembelajaran, siswa dapat mengikuti dengan baik.

Pada pertemuan pertama, guru memulai pembelajaran dengan memberikan pengetahuan bahwa konsep sudut sering dibutuhkan oleh seseorang dalam kehidupan sehari-hari. Selanjutnya guru mengajarkan siswa cara menghitung sudut menggunakan jarum jam panjang dan jarum jam pendek dengan bantuan jam dinding lingkaran. Setelah itu, siswa dikelompokkan menjadi 4 sampai dengan 5 siswa setiap kelompoknya, dan dibagikan sebuah alat peraga jam dinding lingkaran, serta LAS di setiap kelompok. Guru memberikan arahan kepada siswa untuk berdiskusi dalam menyelesaikan permasalahan sudut pada LAS. Kegiatan selanjutnya yaitu pada saat siswa mengerjakan LAS, guru berkeliling kelas untuk mengecek pekerjaan kelompok dan memberikan bantuan kepada kelompok yang mengalami kesulitan dalam menjawab permasalahan dalam LAS. Tindakan bimbingan yang dilakukan oleh guru tanpa memberikan secara langsung konsep sudut ini merupakan tindakan guided reinvention pada PMRI atau yang biasa dikenal dengan model pembelajaran guided inquiry. Lestari dan Prahmana (2017) pada penelitiannya, menyatakan bahwa dalam pembelajaran guided inquiry guru tidak diperbolehkan untuk langsung menjelaskan konsep, sifat-sifat, maupun jawaban atas materi yang sedang dipelajari oleh siswa. Hal tersebut sejalan dengan pernyataan Zulkardi dan Putri (2010) bahwa pada pendekatan PMRI peran guru tak lebih dari fasilitator, moderator atau evaluator. Oleh karena itu, pada pembelajaran ini, posisi guru adalah sebagai fasilitator saja dan hanya diperbolehkan untuk membimbing siswa dalam menemukan konsep sudut.

Pada pertemuan kedua, guru memulai pembelajaran dengan memberikan gambaran materi yang dipelajari pada pertemuan tersebut dan mereview kembali materi pertemuan yang lalu yaitu tentang besar sudut dan jenis-jenis sudut berdasarkan besar sudutnya. Selanjutnya, guru mengajarkan cara menghitung besar sudut pada jam dinding lingkaran melalui jarum jam panjang dan jarum jam pendek pada jam dinding lingkaran. Setelah itu, guru menginformasikan bahwa di akhir pelajaran diadakan tes evaluasi mengenai materi sudut yang telah dipelajari. Kemudian guru membagi kelompok yang setiap kelompoknya terdiri dari 4 sampai dengan 5 siswa, dan dibagikan sebuah jam dinding lingkaran, serta LAS di setiap kelompok. Guru memberikan arahan kepada siswa untuk berdiskusi dalam menyelesaikan permasalahan sudut pada LAS. Pada saat siswa mengerjakan LAS, guru berkeliling kelas untuk mengecek pekerjaan kelompok dan 
memberikan bantuan kepada kelompok yang mengalami kesulitan. Kasus kesulitan yang didapatkan yaitu siswa tidak dapat memahami konsep sudut yang diterapkan dalam kehidupan sehari-hari. Hal tersebut dikarenakan siswa masih memiliki pola pikir yang abstrak sehingga siswa mengalami kesulitan untuk menerapkan matematika dalam kehidupan sehari-hari atau dalam kehidupan nyata (Adrelia, Kurniawati, \& Prahmana, 2015; Hanum \& Prahmana, 2019). Sehingga guru membantu dan membimbing beberapa siswa yang kesulitan hingga siswa tersebut paham. Selanjutnya guru membagikan soal tes evaluasi kepada seluruh siswa. Setelah waktu untuk mengerjakan tes evaluasi yang telah ditentukan habis, guru segera mengambil seluruh pekerjaan siswa.

Selain data proses pembelajaran, data hasil belajar siswa juga sangat penting karena untuk mengetahui bagaimana implementasi desain pembelajaran garis dan sudut yang telah dirancang. Hasil tes tertulis menunjukkan bahwa masih terdapat siswa yang belum dapat menyelesaikan soal-soal tes evaluasi dengan benar. Secara umum, kategori untuk soal paling sulit berdasarkan skor yang diperoleh siswa adalah soal nomor 5 dikarenakan dari 21 siswa, terdapat 8 siswa yang jawaban hasil tesnya belum benar. Sedangkan soal yang paling mudah adalah soal nomor 3 tentang mencari besar sudut tekecil. Pada soal nomor 3 tersebut, hanya terdapat 1 orang siswa yang tidak dapat menjawab dengan benar.

Kesalahan-kesalahan siswa dalam mengerjakan soal tes evaluasi salah satunya disebabkan karena kurang telitinya siswa dalam mengubah pecahan campuran ke pecahan biasa. Kesalahan lainnya adalah salah dalam menghitung lompatan pada jarum jam dinding lingkaran. Selain itu, siswa kurang memahami jenis-jenis sudut berdasarkan besar sudutnya, sehingga siswa tidak dapat menjawab soal dengan maksimal.

Data hasil tes tertulis setelah siswa diberikan treatment menunjukkan bahwa ratarata nilai siswa adalah 84,05. Lebih lanjut lagi, dari 21 siswa, frekuensi siswa yang tuntas pada tes tertulis ini adalah sebanyak 17 siswa, dengan 7 siswa diantaranya mendapatkan nilai tertinggi yaitu 100. Sedangkan frekuensi siswa yang tidak tuntas adalah sisanya yaitu 4 siswa. Lebih jelasnya, untuk data hasil tes tertulis siswa dapat dilihat pada lampiran. Dari uraian di atas dapat dikatakan bahwa pembelajaran garis dan sudut menggunakan pendekatan PMRI atau RME efektif ditinjau dari prestasi belajar dengan persentase ketuntasan $81 \%$. 


\section{SIMPULAN DAN SARAN}

Desain pembelajaran garis dan sudut menggunakan konteks jam dinding lingkaran berperan dalam pemahaman konsep garis dan sudut. Aktivitas menggunakan alat peraga atau menggambar jam dinding lingkaran dapat mendorong siswa untuk melihat bentuk sudut yang terbentuk, dan ketika siswa melihat bentuk sudut tersebut, siswa memiliki ide untuk menghitung besar sudut yang di bentuk oleh kedua jarum jam dan dapat menentukan jenis-jenis sudut tersebut berdasarkan besar sudutnya. Sehingga, desain tersebut dapat membantu siswa memahami konsep sudut melalui konteks jam dinding lingkaran. Selanjutnya, guru membimbing siswa untuk menemukan konsep sudut melalui peristiwa yang ada dikehidupan sehari-hari menggunakan pembelajaran garis dan sudut melalui LAS berbasis pendekatan PMRI. Selain itu, pada saat pengenalan konsep sudut, siswa diajak untuk melakukan eksperimen dengan cara menentukan besar sudut antara kedua jarum jam menggunakan alat peraga jam dinding lingkaran. Pada pertemuan pertama dan kedua, siswa terlihat aktif dan dapat mengikuti pembelajaran dengan baik. Selanjutnya, peneliti menyarankan para guru untuk dapat menggunakan bahan ajar berupa LAS yang berbasis pendekatan Pendidikan PMRI sebagai salah satu alternatif mengajar siswa untuk mengenalkan konsep sudut.

\section{DAFTAR RUJUKAN}

Adrelia, D. I., Kurniawati, V., \& Prahmana, R. C. I. (2015). Permainan bom angka dalam konsep kelipatan persekutuan terkecil untuk anak Sekolah Dasar. Jurnal Elemen, 1(1), 25-35.

Afrilianto, M. (2012). Peningkatan pemahaman konsep dan kompetensi strategis matematis siswa SMP dengan pendekatan metaphorical thinking. Infinity Journal, 1(2), 192-202.

Akmil, A. R., Armiati, \& Rizal, Y. (2012). Implementasi CTL dalam meningkatkan pemahaman konsep matematika siswa. Jurnal Pendidikan Matematika,1(1), 24-29.

Edo, S. I., \& Bulu, V. R. (2018). Penanaman pemahaman hubungan antara bilangan pada siswa baru sekolah dasar melalui pembelajaran PMRI. Journal of Honai Math, 1(2), 139-154.

Fitri, N. L., \& Prahmana, R. C. I. (2018). Pembelajaran luas segiempat untuk siswa kelas VII menggunakan Reallotment Activities. Jurnal Review Pembelajaran Matematika, 3(1), 18-28. 
Hanun, A., \& Prahmana, R. C. I. (2019). Pembelajaran luas permukaan prisma menggunakan konteks packaging. Jurnal Riset Pendidikan dan Inovasi Pembelajaran Matematika (JRPIPM), 2(2), 70-79.

Herawati, O. D. P., Siroj, R. A., \& Basir, M. D. (2010). Pengaruh pembelajaran problem posing terhadap kemampuan pemahaman konsep matematika siswa kelas XI IPA SMA Negeri 6 Palembang. Jurnal Pendidikan Matematika, 4(1), 70-80.

Khoirudin, \& Rizkianto, I. (2018). Pengembangan perangkat pembelajaran problem based learning dan learning trajectory yang berorientasi pada kemampuan penalaran matematis siswa. Mosharafa: Jurnal Pendidikan Matematika, 7(2), 207-218.

Lestari, R. M., \& Prahmana, R. C. I. (2017). Model guided inquiry, student team achievement division dan kemampuan penalaran matematis siswa. Beta: Jurnal Tadris Matematika, 10(2), 153-165.

Mumu, J., \& Tanujaya, B. (2018). Desain pembelajaran materi operasi pada himpunan menggunakan permainan "Lemon Nipis". Journal of Honai Math, 1(1), 14-23.

Prahmana, R. C. I. (2017). Design Research: (Teori dan implementasinya: Suatu Pengantar). Depok: PT Raja Grafindo Persada.

Purwanti, R. D., Pratiwi, D. D., \& Rinaldi, A. (2016). Pengaruh Pembelajaran Berbatuan Geogebra terhadap Pemahaman Konsep Matematis ditinjau dari Gaya Kognitif. AlJabar: Jurnal Pendidikan Matematika, 7(1), 115-122.

Risdiyanti, I., Prahmana, R. C. I., \& Shahrill, M. (2019). The learning trajectory of social arithmetic using an Indonesian traditional game. Elementary Education Online, 18(4), 2094-2108.

Sari, A. P. (2014). Pengaruh Pendidikan Matematika Realistik Indonesia terhadap pemahaman konsep siswa pada materi untung dan persentase untung. Jurnal Pendidikan Matematika, 8(2), 1-19.

Sary, R. M., \& Ristiana, R. (2019). Pembelajaran keliling dan luas bangun datar menggunakan metode matematika gasing. Journal of Honai Math, 2(2), 143-150.

Simanulang, J. (2013). Pengembangan bahan ajar materi himpunan konteks laskar pelangi dengan pendekatan Pendidkan Matematika Realistik Indonesia (PMRI) Kelas VII Sekolah Menengah Pertama. Jurnal Pendidikan Matematika, 7(2), 26-36.

Suryanti, O. C. (2015). Identifikasi Berpikir Kritis dalam Pemecahan Masalah Matematika Pokok Bahasan Garis dan Sudut pada Siswa Kelas VII-E SMP Negeri 4 Jember. Skripsi, Tidak dipublikasikan. Jember: Universitas Jember. 
Susanto, A. (2015). Teori Belajar dan Pembelajaran di Sekolah Dasar. Jakarta: Prenada Media Group.

Susilowati, N. (2017). Analisis Hambatan Berpikir Kritis Siswa dalam Menyelesaikan Soal Materi Garis dan Sudut Berdasarkan Teori Bruner. Skripsi, Tidak dipublikasikan. Semarang: Universitas Islam Sultan Agung.

Wachidah, L. (2015). Kemampuan Berpikir Kreatif Siswa dalam Menyelesaikan Soal Matematika Materi Garis dan Sudut pada Siswa Kelas VII A MTSN 2 Tulungagung Tahun Ajaran 2014/2015. Skripsi, Tidak dipublikasikan. Tulungagung: Institut Agama Islam Negeri (IAIN).

Zulkardi \& Putri, R. I. I. (2010). Pengembangan blog support untuk membantu siswa dan guru matematika Indonesia belajar Pendidikan Matematika Realistik Indonesia (PMRI). Jurnal Inovasi Perekayasa Pendidikan (IIPP), 2(1), 1-24. 